\title{
IZABELA SPIELVOGEL
}

Politechnika Opolska

ORCID: 0000-0003-2255-0727

MARIA PAJĄK

Uniwersytet Opolski

ORCID: 0000-0002-2179-3340

DOI: 10.4467/12311960MN.21.012.15240

\section{Terra sigillata Silesiaca - historyczne pokłady śląskiej gliny leczniczej jako środek terapeutyczny}

\section{Terra sigillata Silesiaca - historical deposits of Silesian medicinal clay as therapeutic agent}

\section{Summary}

Clays, because of their medicinal properties, have been intuitively used in healing in all parts of the world since ancient times. The discovery of medicinal clay deposits used in Silesia - terra sigillata Silesiaca - dates back to 1550 . The deposits were described in 1586 in a work published in Nuremberg entitled Judieum de terra sigillata strigoviensis. The author of the publication was the discoverer of Silesian healing clays - a Renaissance physician and geologist from Strzegom - Johann Schulz (1531-1604), known as Johannes Montanus. This discovery was also mentioned in 1583 by Andreas Berthold, an alchemist and empiricist, who was not a physician, in his work entitled Terrae sigillatae nuper in Germania repertae and Caspar Schwenckfeld (1563-1609), a spa physician from Cieplice-Zdrój, in his monograph from 1600, entitled Stirpium \& Fossilium Silesiae Catalogus. Indications for using clay from Silesian deposits were also described in a work from 1737, entitled Rariora naturae \& artis, item in re medica; oder, Seltenheiten der Natur und Kunst des kundmannischen Naturalien-Cabinets, wie auch in der Artzeney-Wissenschafft by Johann Kundmann (1684-1751), a physician of the von Hochberg 
family from Wrocław. By 1580, Silesian clay was already known as a remedy against dog rabies in the state of Hesse. In 1618, it was listed in the pharmaceutical work entitled Pharmacopoetia Londinensis, alongside clays from the Mediterranean region. According to the descriptions, this clay helped the population in 1633 as a prophylactic measure to control the plague epidemic and the mass extinction of cattle in Upper Silesia.

Słowa kluczowe: historia medycyny, śląska glina lecznicza, terra sigillata Silesiaca, Śląsk

Key words: history of medicine, Silesian medicinal clay, terra sigillata Silesiaca, Silesia

Glinki, ze względu na ich właściwości lecznicze, były intuicyjnie wykorzystywane w lecznictwie we wszystkich częściach świata od najdawniejszych czasów. Odkrycie pokładów gliny stosowanej w lecznictwie na Śląsku - terra sigillata Silesiaca datowane jest na 1550 r. Złoża zostały opisane w $1586 \mathrm{r}$ w dziele wydanym w Norymberdze pt. Judieum de terra sigillata strigoviensis. Autorem publikacji był odkrywca śląskich glin leczniczych - renesansowy lekarz, przyrodolecznik i geolog pochodzący ze Strzegomia - Johann Schulz (1531-1604), znany jako Johannes Montanus. O odkryciu tym wspomniał także w $1583 \mathrm{r}$. alchemik i empiryk niebędący lekarzem - Andreas Berthold w opublikowanej po łacinie pracy pt. Terrae sigillatae nuper in Germania repertae oraz Caspar Schwenckfeld (1563-1609), lekarz zdrojowy z Cieplic, w monografii z 1600 r. Stirpium \& Fossilium Silesiae Catalogus. Wskazania do stosowania gliny ze śląskich pokładów zostały opisane także w dziele z 1737 r. pt.: Rariora naturae \& artis, item in re medica; oder, Seltenheiten der Natur und Kunst des kundmannischen NaturalienCabinets, wie auch in der Artzeney-Wissenschafft przez pochodzącego z Wrocławia lekarza rodziny von Hochbergów - Johanna Kundmanna (1684-1751). W 1580 r. glina śląska była już znana jako środek leczniczy przeciw psiej wściekliźnie w landzie Hesja w Niemczech Zachodnich. W 1618 r. została wymieniona w dziele farmaceutycznym Pharmacopoetia Londinensis obok glinek rejonu śródziemnomorskiego. Według opisów glina ta pomogła w 1633 r. ludności jako środek profilaktyczny w opanowaniu epidemii dżumy oraz w masowym wymieraniu bydła na Górnym Śląsku. Prace naukowe dotyczące śląskich glin leczniczych doczekały się publikacji przede wszystkim w literaturze obcojęzycznej, dlatego podstawowym materiałem badawczym w artykule były źródła 
niemieckie. W przedwojennej bibliografii polskiej historiografii farmaceutycznej tematyka Terra sigillata silesiaca jest skromna, np. Teodor Heinrich i Szymon Fabian w publikacji pt. Farmacya z 1835 r. w jednym tylko zdaniu wspominają o śląskich glinach leczniczych. Tematyka związana z materiałami ilastymi stosowanymi w lecznictwie w polskim piśmiennictwie powojennym pojawiła się przede wszystkim $\mathrm{w}$ pracach popularyzatorskich, np. K. Kaszub, Terra Sigillata de Strigovia z 2004 r. Publikacjami naukowymi w języku polskim na ten temat sa prace: W. Roeske, Terra Sigillata Liegnicensis z 1967 r., W. Kowalskiego i A. Wiewióry, Terra Sigillata, która ukazała się w 1974 r. w periodyku „Prace Muzeum Ziemi”, oraz katalog zbiorów Muzeum Porcelany w Wałbrzychu opracowany w 1988 r. przez E. Sagana i M. Pakieta. $\mathrm{Z}$ tego materiału wyłania się jednak dość istotny brak - słabe rozpoznanie wąskiej problematyki, jaką jest temat górnośląskich glin leczniczych. Temat tego artykułu podjęty został jako próba wypełnienia tej luki oraz próba uporządkowania informacji na temat stosunkowo mało znanego zagadnienia, jakim jest temat śląskich glin leczniczych. Śląska glina lecznicza jako surowiec terapeutyczny został obecnie zupełnie zapomniany, podczas gdy w ostatnim czasie na świecie można zauważyć zwiększone zainteresowanie właściwościami geochemicznymi tych minerałów, zwłaszcza w kontekście bakteriobójczym. W tym celu dokonano analizy źródeł i opracowań, syntetycznie uporządkowano oraz zaktualizowano wiadomości na temat śląskich materiałów ilastych stosowanych w medycynie dawnej.

\section{Glinki jako środek terapeutyczny na przestrzeni wieków}

Glinki były wykorzystywane w lecznictwie we wszystkich częściach świata od najdawniejszych czasów, o czym wspominał już Arystoteles (384-322 p.n.e.) ${ }^{1}$. W medycynie ludowej stosowano je zewnętrznie i wewnętrznie m.in. jako środek aseptyczny, ściągający i absorbujący ${ }^{2}$. W I w. n.e. Pliniusz Starszy (23-79) opisał walory lecznicze glinek występujących w Lemnos, Erytrei, Samos, Chios i Melos. Reputacja ziem leczniczych została ugruntowana w II w. n.e.

${ }^{1}$ Por. K.H. Dannenfeld, The introduction of a new sixteen - century drug: terra Silesiaca, „Medical History” 1984, nr 28, s. 174-188; L.B. Wiliams, S.E. Haydel, Evaluation of the medicinal use of clay minerals as antibacterial agents, „International Geology Review" 2010, vol. 52, nr 7/8, s. 745-770; C.S Gomes, Naturotherapies Based on Minerals, „Geomaterials” 2013, vol. 3, no. 1, s. 1-14; W. Roeske, Terra Sigillata Liegnicensis „Biuletyn Informacji Polfa” 1967, nr 2, s. 56.

2 D. Czubala, O ludowym leczeniu glina w Polsce. Na podstawie badań przeprowadzonych w Polsce wśród garncarzy, „Lud” 1984, t. 68, s. 181-195. 
przez greckiego lekarza Galena ${ }^{3}$ (130-210), który w dziewiątej księdze swego dzieła pt. De simplicium medicamentorum temperamentis ac facultatibus opisał ziemie lecznicze stosowane w lecznictwie tradycyjnym $^{4}$. Kierując się własnym doświadczeniem i przekazami, podał wskazania do ich stosowania, przy czym skupił się przede wszystkim na działaniu glinek z Lemnos, nazwanych terra sigillata Lemnia. Glinka ta wykorzystywana była przez miejscową ludność w leczeniu wrzodów, ran, biegunki, ukąszeń węży, wściekłych psów i innych zwierząt $^{5}$. Średniowieczny lekarz Avicenna (980-1037), podobnie jak muzułmański lekarz i farmakoterapeuta Ibn al-Baitar (1197-1248) wspominali w swych dziełach m.in. o pozostających $\mathrm{w}$ użyciu $\mathrm{w}$ tradycyjnej medycynie ludowej glinach z Lemnos i Samos. Pod koniec $\mathrm{XV}$ w. o glinach leczniczych pisano m.in. w słynnym dziele Gart der Gesundheit z 1470 r., wydanym w Moguncji na zlecenie Bernharda von Breidenbacha (1440-1497) ${ }^{6}$. W XVI w. lekarz i chirurg Paracelsus (1493-1541) po raz pierwszy terminem terra sigillata nazwał glinkę z Malty. Od tego momentu termin ten przestał być używany jedynie w kontekście glinki z Lemnos. Natomiast Bernard Palissy (1510-1589), francuski ceramik, geolog i przyrodnik, w swym dziele Discours admirables z $1580 \mathrm{r}$. starał się wyjaśnić działanie terra sigillata Lemnia. Doszedł też do wniosku, że ten rodzaj glinki może występować również $\mathrm{w}$ innych miejscach na Ziemi. Jego przypuszczenie okazało się trafne. Wskazywał on na jej występowanie w Turcji, jednak podobne tworzywo lecznicze - terra sigillata Silesiaca - odkryto w XVI w. w Europie Centralnej - na Śląsku, pozostającym wówczas w granicach imperium

${ }^{3}$ Galen był reformatorem nie tylko w zakresie leczenia chorób, ale także był pionierem przygotowywania leków. Osobiście, bardzo starannie wykonywał mieszanki lecznicze i medykamenty w swojej aptece w Rzymie przy Via Sacra, przywiązując ogromną wagę do postaci leku. Galen wprowadził nowe wówczas formy leków, np.: delikatne proszki, wyciągi, nalewki, pastylki, pigułki, powidełka, środki do pędzlowania i wcierana, plastry, okłady i in., a więc formy, które stosowane są do dzisiaj. Ten zakres działalności stał się początkiem nowej dyscypliny, nazwanej dzisiaj farmacją stosowaną bądź od nazwiska twórcy - farmacją galenową. Co się tyczy samych środków leczniczych używanych i stosowanych przez Galena, to ich liczba, jak na owe czasy, była imponująca: samych środków roślinnych Galen wymienia 473. Z leków mineralnych w jego aptece zastosowanie znalazły: związki ołowiu, miedzi, żelaza, arszenik, sól morska, gips, glinka, siarka, ałun, soda i wiele innych. Por. A. Drygas, Zarys dziejów farmacji z elementami zagadnień metodologicznych dla studentów farmacji, Gdańsk 1994, s. 70-71.

${ }^{4}$ H Pankiewicz., Terra Sigillata, „Farmacja Polska” 1985, t. 41, nr 7, s. 395.

${ }^{5}$ I. Spielvogel, K. Spałek, K. Badora, J. Procków, Traditional knowledge and practice of the Triassic variegated clay from Silesia (Krasiejów), Poland, in human medicine, ,Journal of Ethnobiology and Ethnomedicine” 2021, $\mathrm{nr}$ 17, $\mathrm{nr}$ art. 10, https://doi. org/10.1186/s13002-019-0298-z.

${ }^{6}$ K.H. Dannenfeld, op. cit., s. 174. 
Terra sigillata Silesiaca - historyczne pokłady śląskiej gliny leczniczej...

Habsburgów ${ }^{7}$. Lecznicze wykorzystanie glinek (terra sigillata medicorum) w etnolecznictwie m.in. przez garncarzy, zarówno u ludzi, jak i zwierząt domowych, znane było do XIX w. w różnych miejscach niezależnych od siebie kulturowo czy religijnie ${ }^{8}$. $\mathrm{O}$ zabiegach $\mathrm{z}$ użyciem okładów z gliny przeciw owrzodzeniom, trudno gojącym się ranom ciętym lub kutym, przeciw ukąszeniom owadów i wspomagających epidemię cholery pisał np. pod koniec XIX w. ks. Sebastian Kneipp (18211897), działający w Bawarii twórca terapii profilaktyczno-leczniczej, wpisanej w 2015 r. na listę niematerialnego dziedzictwa UNESCO.

\section{Historyczne złoża gliny leczniczej na Śląsku i ich zastosowanie $w$ medycynie dawnej}

Odkrycie pokładów gliny stosowanej w lecznictwie na Śląsku terra sigillata Silesiaca datowane jest na $1550 \mathrm{r}$. W $1583 \mathrm{r}$. wspomniał o nich alchemik i empiryk niebędący lekarzem - Andreas Berthold of Oschatz z Saksonii w pracy pt. Terrae sigillatae nuper in Germania repertae ${ }^{9}$. Opisał tam śląską glinę leczniczą m.in. jako środek ratujący życie po spożyciu trucizny i o fakcie tym poinformował landgrafa Hesji-Kassel - Wilhelma IV Mądrego (1532-1592). Władca powierzył sprawę swoim dwóm nadwornym lekarzom i nakazał im przeprowadzenie prób medycznych w 1580 i $1581 \mathrm{r}$. Lekarze w ramach eksperymentu podali truciznę dwóm psom oraz jednemu skazańcowi, a następnie glinę śląską jako antidotum. Wszyscy mieli próbę przeżyć ${ }^{10}$. O terra sigillata Silesiaca wspominał również Caspar Schwenckfeld (1563-1609)11 w monografii pt. Stirpium \& Fossilium Silesiae Catalogus. Był to lekarz zdrojowy z Cieplic Śląskich, botanik, mineralog, zoolog i przyrodnik regionu karkonoskiego, zaliczany do grona najwybitniejszych śląskich uczonych doby odrodzenia. Jednak najstarsze lekarskie informacje pisane związane ze śląskimi pokładami gliny leczniczej pochodzą z 1586 r. Złoża te opisane zostały przez ich odkrywcę w wyda-

${ }^{7}$ K. Brunner, Schlesische terra sigilata, [w:] K. Weinhold, J. Bolte, H. Michel (red.), „Zeitschrift des Vereins für Volkskunde” 1911, r. 21, z. 4, s. 345-351; A. Steinbeck, Ueber die Siegelerde von Striegau, „Jahres-Beticht der Schlesischen Gesellschaft für vaterländische Kultur" 1856, r. 34, s. 25.

${ }^{8}$ D. Czubala, op. cit., s. 181-195; C.S. Gomes, Healing and edible clays: a review of basic concepts, benefits and risks, „Environmental Geochemistry and Health” 2018, nr 40, s. 1739-1765.

9 A. Berthold, Terrae sigillatae nuper in Germania repertae, Frankfurt am Main 1583.

${ }^{10}$ A. Rankin, On anecdote and antidotes: Poison trials in sixteenth-century Europe, „Bulletin of the History of Medicine” 2017, vol. 91, no. 2, s. 274-302.

${ }^{11}$ C. Schwenckfeld, Stirpium \& Fossilium Silesiae Catalogus, Görlitz 1600. 
nym w Norymbergii dziele pt. Judieum de terra sigillata strigoviensis. Autorem był renesansowy lekarz i geolog Johann Schulz (1531-1604), znany jako Johannes Scultetus Trimontanus lub Johannes Montanus ${ }^{12}$. Był on synem chirurga działającego w Strzegomiu, studiował na Uniwersytecie w Bolonii. W 1557 r. ukończył studia i rozpoczął pracę lekarza w Jeleniej Górze. Autor opisał w swym dziele trzy rodzaje śląskiej gliny leczniczej terra sigillata Silesiaca: glinę ze Strzegomia - terra sigillata Strigoniensis (nazywaną też Monits Acuti), glinę z Legnicy - terra sigillata Lignicensis oraz glinę ze Złotoryi - terra sigillata Godtbergensis ${ }^{13}$. Dzięki swemu odkryciu Montanus zyskał sławę i został osobistym lekarzem cesarza Rudolfa II (1576-1611). Johannes Schulz w swym opisie terra sigillata Silesiaca wyodrębnił dwa rodzaje glinek: czerwoną i białą. Pierwszą określił złotem, które przez słońce zmienione zostało w glinkę czerwoną, nazwał ją więc Axungia Solis. Glinka biała powstać miała w ten sam sposób, lecz w wyniku działania księżyca, dlatego nosiła nazwę Axungia Lunae ${ }^{14}$. Montanus skupił się w swych opisach szczególnie na wskazaniach leczniczych do stosowania gliny strzegomskiej. Jej występowanie stwierdził w trzech górach pasma Gór Strzegomskich: Breitenberg (Góra Szeroka), Georgenberg (Góra Bazaltowa), Kreuzberg (Góra Krzyżowa) ${ }^{15}$. W 1580 r. glina śląska była już znana jako środek leczniczy przeciw psiej wściekliźnie w Hesji, a w 1852 r. można było nabyć ją na targach we Frankfurcie ${ }^{16}$. W 1618 r. terra Silesiaca została wymieniona w dziele farmaceutycznym pt. Pharmacopoetia Londinensis, obok klasycznych glinek rejonu śródziemnomorskiego ${ }^{17}$. W 1589 r. Magistrat strzegomski uzyskał cesarski przywilej do wydobywania gliny strzegomskiej na okres sześciu lat. W 1594 r. pozwolenie przedłużono o kolejne dziesięć, a w 1614 r. o dwadzieścia lat. Oczyszczoną glinę formowano w krążki o średnicy ok. 1 cala $(24 \mathrm{~mm})$ i grubości 0,5 cala. $\mathrm{Na}$ tak przygotowanych pastylkach odciskano stempel określający pochodzenie krążka oraz potwierdzający jego autentyczność. Najczęściej używano pieczęci z przedstawieniem trzech strzegomskich

12 Por. K.H. Dannenfeld, op. cit., s. 176; K. Brunner, op. cit., s. 348.

${ }^{13}$ G.A. Volkmann, Silesia subterranea, oder Schiesien, mit seinen Unterirdischen Schatzen, Seltsamheiten, Leipzig 1720, s. 275-289.

${ }^{14}$ C. Duffin, „Fish”, fossil and fake: medicinal unicorn horn, [w:] C. Duffin, C. Gardner-Thorpe, R.T.J. Moody (red.), Geology and Medicine: Historical Connections, London 2017, s. 236.

15 J.H. Zedler, Grosses vollständiges Universal Lexicon aller Wissenschaften und Künste, Leipzig und Halle 1744, t. 42, s. 1115.

${ }^{16}$ P.J. Marperger, Schlesischer Kauffmann, Breslau-Leipzig 1714, s. 179.

17 K.H. Dannenfeld, op. cit., s. 186. 
Terra sigillata Silesiaca - historyczne pokłady śląskiej gliny leczniczej...

wzgórz. Poniżej znajdował się napis terra Sigillata Stregoniensis lub Stregonien, względnie Strigoniensis, często w formie skrótu wraz z rokiem produkcji. Niekiedy stosowano stempel z przedstawieniem dwugłowego orła dla podkreślenia związku surowca z Cesarstwem Austriackim $^{18}$. W 1542 r. we Wrocławiu wybuchła epidemia dżumy. Wśród dokumentacji relacjonującej przebieg zarazy można natrafić na opis tzw. teriaków, czyli mieszanin terra sigillata z ziołami i roślinami leczniczymi. Leki produkowane były w dwóch wersjach - dla biednych i zamożnych, a różniły się między sobą proporcjami poszczególnych składników ${ }^{19}$. W XVII w. wszystkie gminy lub miasta posiadające na swoim terenie ziemie, których właściwości mogły być zbliżone do złóż strzegomskich, dążyły do uzyskania opinii potwierdzającej ich skuteczność medyczną. Często stosowano do oznakowania tych pastylek układ stempla zbliżonego do pieczęci strzegomskiej, co nie sprzyjało interesom Strzegomia. W 1685 r. wprowadzono nakaz cesarski do bezwzględnego pieczętowania gliny pozyskiwanej także $\mathrm{z}$ innych śląskich pokładów nazwą miejscowości $^{20}$. Były to pokłady w miejscowościach: Strzegom (Striegau), Złotoryja (Goldberg), Janowice Duże koło Legnicy (Groß Jänowitz.), Legnica (Liegnitz), Sichów (Seichau), Jawor (Jauer), Dzierżoniów (Reichenbach), Brachów (Brechelwitz), Masłów koło Trzebnicy (Massel). Na Górnym Śląsku znane były glinki: czerwona z Płużnicy (Groß Pluschnitz) koło Strzelec Opolskich (Gross Strehlitz) oraz biała z okolic Olesna (Rosenberg), a także z Boroszowa (Boroschau), nazywana terra Nobarsovensis ${ }^{21}$ (ryc. 1). Glinka ta odkryta została w 1700 r. przez Gottfrieda Wahla - pochodzącego ze Świebodzic (Freiburg) radnego z Oleśnicy (Oels). Paul Jakob Marperger $(1656-1730)^{22}$ w 1714 r. wspomniał o jej działaniu antytoksycznym

${ }^{18}$ E. Sagan, M. Pakiet, Terra Sigillata (katalog zbioru), Wałbrzych 1988, s. 9.

${ }^{19}$ Ibidem, s. 10.

${ }^{20}$ G.A. Volkmann, op. cit., s. 273.

21 Por. D. Grebner, Tractatus philologico-physico-medici septem, uno volumine comprehensi, Vratislavia 1703, s. 77; L.D. Hermann, Maslographia oder des schlesischen Massel im Oelss-Bernstäditischen Fürstenthum mit seinen Schauwürdigkeiten, Breslau 1711, s. 188; K. Spałek, I. Spielvogel, The Use of Medicinal Clay from Silesia „terra sigillata Silesiaca“, Central Europe - A New Chance for Natural Medicine?, „Biomedical Journal of Scientific \& Technical Research“ 2019, t. 20, nr 3, s. 15057-15061.

${ }^{22}$ Urodził w Norymberdze i już w wieku 10 lat rozpoczął studia na wydziale teologicznym uniwersytetu w Altdorfie. Następnie rozpoczął praktykę ekonomiczną w domu handlowym w Lyonie we Francji, gdzie zapoznał się z zaawansowanymi metodami francuskiego handlu. Odbył liczne podróże, np. do Genewy, Hamburga, Lubeki, Kopenhagi, Moskwy, Petersburga. Doświadczenia z podróży opisał w licznych publikacjach. Był pierwszym niemieckim pisarzem zajmującym się ekonomią, gospodarką i rachunko- 
i przeciwgorączkowym, wskazana była też w przypadku dolegliwości żołądkowych ${ }^{23}$. Od XVI do XVIII w. z terra sigillata Silesiaca wyrabiano naczynia użytkowe. W okolicach Masłowa w XVIII w. poza wieloma glinianymi naczyniami odkryto także pastylki wykonane z gliny, a używane jako lekarstwo. Pastylki te nazywano Töppelberg - od miejsca odkrycia, wzgórza Töppelberg (Wzgórze Urn), znajdującego się w zachodniej części tej miejscowości ${ }^{24}$. Strzegomska glina według opisu Marpergra stosowana była przy trudno gojących się ranach powstałych z ukąszenia lub pogryzienia. Stosowana była zarówno zewnętrznie pod postacią okładów i kompresów, jak i wewnętrznie - w postaci płynnego roztworu $\mathrm{z}$ wodą, winem, piwem, octem lub w postaci pastylek. Okład mógł być wykonany także po zmieszaniu glinki ze śliną pacjenta pozostającego na czczo, który od paru dni nie jadł cebuli, czosnku i mięsa wieprzowego ${ }^{25}$. Wskazana była w leczeniu ran po ugryzieniu psa zarażonego wścieklizną. Innymi wskazaniami były: problemy jelitowe, wzdęcia, zatwardzenia, choroby oczu, krwawienie $\mathrm{z}$ nosa, krwawienie z ran, bóle głowy, gorączka oraz zapobieganie epidemii cholery ${ }^{26}$. Wskazania do leczniczego stosowania gliny ze śląskich pokładów zostały opisane także w dziele pt. Rariora naturae \& artis, item in re medica; oder, Seltenheiten der Natur und Kunst des kundmannischen Naturalien-Cabinets, wie auch in der Artzeney-Wissenschafft przez lekarza rodziny von Hochbergów - Johanna Kundmanna (1684-1751) ${ }^{27}$. Naczynia wykonane z glinki terra sigillata wy-

wością podatkową. Swoimi obserwacjami wzbudził duże zainteresowanie środowisk gospodarczych i naukowych, a w 1708 r. został przyjęty do Pruskiego Towarzystwa Naukowego (Preußische Akademie der Wissenschaften). Jest autorem ponad 60 publikacji z dziedziny ekonomii, botaniki, medycyny, bankowości i in. Por. H.P. Harstick, Der Kameralist Paul Jacob Marperger (1856-1730) über Armenwesen und Armenfürsorge, [w:] U. Becker, H.M. Becker, J. Kloosterman (red.), Kein Nachruf! Beiträge über und für Götz Langkau, Amsterdam 2003, s. 44-52.

${ }^{23}$ P.J. Marperger, op. cit., s. 180; J.H. Zedler, op. cit., s. 1115.

${ }^{24}$ Wzgórze Töppelberg (Wzgórze Urn) pod Trzebnicą na Dolnym Śląsku opisane zostało przez Leonharda Davida Hermanna (1670-1736) - miejscowego pastora i pioniera śląskiej archeologii. Wydana przez niego we Wrocławiu publikacja pt. Maslographia oder des schlesischen Massel im Oels-Bernstäditischen Fürstenthum mit seinen Schauwürdigkeiten jest pierwszą monografią stanowiska archeologicznego z terenu Śląska. W opracowaniu tym znajdują się opisy m.in. antycznych i średniowiecznych monet, naczyń glinianych, pastylek leczniczych oraz innych cennych artefaktów archeologicznych.

${ }_{25}$ J.P. Marperger, op. cit., s. 179.

${ }^{26}$ K. Brunner, op. cit., s. 349.

${ }^{27}$ W latach 1704-1707 studiował medycynę we Frankfurcie nad Odrą i Halle, gdzie uzyskał doktorat w $1708 \mathrm{r}$. Po studiach podróżował po Niemczech i Belgii oraz praktykował jako lekarz we Wrocławiu. Jednocześnie pracował $\mathrm{w}$ jednym $\mathrm{z}$ pierwszych czasopism medycznych i naukowych Johanna Kanolda (1679-1729) „Sammlung von Natur und Medicin sowie auch dazugehöriger Kunst und Litteratur Geschichten” (1717). W lutym 
dobywanej ze śląskich złóż, zdaniem Kundmanna, w medycynie ludowej miały mieć właściwości lecznicze. Wierzono np. w to, że temu, kto codziennie pije z naczynia glinianego, temu nie może grozić zatrucie pokarmowe ${ }^{28}$. Czerwona glinka z Płużnicy koło Strzelec Opolskich, nazywana terra sigillata Magni Plussnicensis, odkryta została przez miejscową ludność w dawnej części tej wsi nazywanej Rote Deich (Czerwona Grobla). Zgodnie z opisem Kundmanna glina ta pomogła w 1633 r. jako środek profilaktyczny w opanowaniu epidemii dżumy oraz w czasie masowego wymierania bydła na Górnym Śląsku ${ }^{29}$. Poza zewnętrznymi okładami glinka miała być przez miejscową ludność mieszana $\mathrm{z}$ winem lub piwem i w ten sposób spożywana. W przypadku zwierząt glinka mieszana była z octem i popiołem. Pozwolenie na wydobycie glinki leczniczej w Płużnicy otrzymał szlachcic Andreas von Wehner (1663-1741) - radny z Wrocławia ${ }^{30}$. Opieczętował ją znakiem półksiężyca i trzech strzał ${ }^{31}$. Produkcji tworzywa leczniczego praktycznie zaprzestano w drugiej połowie XVIII w., a pod koniec XVIII w. nazwa terra Sigillata coraz rzadziej pojawia się w lekopisach. Znamienne jest też oświadczenie Magistratu strzegomskiego wskazujące na to, że „glina lecznicza wyszła z mody i jej produkcja staje się nieopłacalna z powodu dużych nakładów ${ }^{32}$ ". Pod koniec XIX w. zainteresowanie glinami leczniczymi zaczęło maleć, tak by na początku XX w. zaniknąć zupełnie. Dziś zbiory pastylek z gliny pochodzących ze Strzegomia i innych rejonów Śląska znajdują się m.in. w Muzeum Porcelany w Wałbrzychu, Muzeum Farmacji w Heildelbergu czy Muzeum Historii Naturalnej w Londynie.

1727 r. został przyjęty do najstarszego niemieckiego towarzystwa naukowego - Deutsche Akademie der Naturforscher Leopoldina, założonego w 1652 r. w Schweinfurcie na wzór renesansowych akademii włoskich jako Epimenides. Był zapalonym numizmatykiem, kolekcjonerem monet, okazów przyrodniczych i dzieł sztuki. Założył gabinet historii naturalnej, którego katalog opublikował w 1737 r. Por. A. Schimmelpfennig, Kundmann, Johann Christian, [w:] Allgemeine Deutsche Biographie, t. 17, Leipzig 1883, s. 377.

${ }_{28} \mathrm{~J} . \mathrm{Ch}$. Kundmann, Rariora naturae \& artis, item in re medica; oder, Seltenheiten der Natur und Kunst des kundmannischen Naturalien-Cabinets, wie auch in der Artzeney-Wissenschafft, Breslau 1737, s. 249-254.

${ }^{29}$ Ibidem, s. 250.

${ }^{30}$ Andreas von Wehner nabył dobra rycerskie: Centawa, Błotnica oraz Płużnica Wielka od Franza Wilhelma von Larischa 12 kwietnia 1706 r. za 36 tys. guldenów. Por. A. Poschadovsky-Wehner, Geschichte des schlesischen uradligen Geschlechtes der Grafen Posadowsky-Wehner Freiherrn von Postelwitz: nebst einem Anhang enthaltend Nachrichten über das Breslauer Patrizier-Geschlecht von Wehner, Breslau 1891, s. 117-120.

${ }^{31}$ Por. C. Duffin, op. cit., s. 126; J.Ch. Kundmann, op. cit., s. 250.

${ }^{32}$ A. Steinbeck, op. cit., s. 27. 


\section{Pierwsze naukowe opracowania dotyczące składu terra sigillata Silesiaca}

Śląsk jest obszarem o bardzo korzystnych warunkach występowania glin, w tym mogących posiadać właściwości lecznicze. Region cechuje się bardzo zróżnicowaną i mozaikowatą budową geologiczną ${ }^{33}$. Na powierzchni występują utwory proterozoiczne, ordowiku, dewońskie, karbońskie, permskie, triasowe, jurajskie, kredowe, paleogenu, neogenu oraz czwartorzędu. W wielu $\mathrm{z}$ nich występują kompleksy glin pochodzące $\mathrm{z}$ wietrzenia (gliny kaolinowe) lub sedymentacji morskiej i limnicznej. Najstarsze gliny pochodzą z wczesnego mezozoiku, natomiast najmłodsze ze zlodowaceń plejstoceńskich i akumulacji rzecznej. Bardzo duża różnorodność mineralogiczno-petrograficzna skał budujących Śląsk decyduje o bardzo dużym zróżnicowaniu glin pochodzących z ich wietrzenia. W południowej części Śląska występują utwory budujące Sudety i Przedgórze Sudeckie. Na większości tego obszaru od paleozoiku skały magmowe, wulkaniczne, metamorficzne ulegały procesom wietrzenia, których efektem jest obecnie występowanie glin kaolinowych. Bardzo korzystne dla występowania tych glin było wietrzenie w ciepłym klimacie mezozoiku i wczesnego kenozoiku. Gliny te zostały stwierdzone m.in. w okolicach Strzegomia i Złotoryi, gdzie udokumentowane jest ich lecznicze wykorzystanie ${ }^{34}$. Północną część Śląska budują osady Monokliny Przedsudeckiej, w obrębie której występują gliny, iły, iłowce i mułowce triasu (głównie górny trias) oraz jury (głównie dolna jura). Osadzały się one w środowisku morskim i limnicznym, ponadto występują też jako zwietrzeliny wapieni triasowych i jurajskich (gliny kaolinowe zasadowe). Gliny jurajskie i triasowe były wykorzystywane leczniczo co najmniej od XVII w., a znane w Europie były m.in. z warstw występujących w okolicach Olesna i Płużnicy (woj. opolskie) ${ }^{35}$.

Pierwsze opracowanie składu chemicznego i po części mineralnego śląskiej gliny leczniczej pochodzi z drugiej połowy XIX w. i dotyczy przede wszystkim gliny ze Strzegomia ${ }^{36}$. Chemicznie, autor uznał ją za

${ }^{33}$ A. Żelaźniewicz, The Sudetes as a Paleozoic orogen in Central Europe, „Geological Magazine” 1997, nr 134, s. 691-702.

${ }_{34}$ Por. A. Macgregor, Medicinal terra sigillata: a historical, geographical and typological review, [w:] C. Duffin, R.T.J. Moody, C. Gardner-Thorpe (red.), A History of Geology and Medicine, London 2013, s. 124-127.

35 J. Don, A. Żelaźniewicz, The Sudetes-boundaries, subdivision and tectonic position, „Neues Jahrbuch für Geologie und Paläontologie” 1990, r. 179, nr 2/3, s. 121-127.

${ }_{36}$ F.W. Jaekel, Über die Bazalte Niederschlesiens, „Jahres-Beticht der Schlesischen Gesellschaft für vaterländische Kultur" 1857, r. 35, s. 31. 
mieszaninę tlenków glinu, krzemu, wapnia i magnezu, a mineralogicznie odpowiadała krzemianom wymienionych pierwiastków. Późniejsze opracowania dotyczące składu mineralnego określono na podstawie badań rentgeno-strukturalnych i analiz spektralnych zostały przeprowadzone przez prof. Włodzimierza Kowalskiego i prof. Andrzeja Wiewióra ${ }^{37}$. Autorzy poddali badaniom geochemicznym 21 próbek z obszaru Dolnego Śląska (Strzegom, Złotoryja, Legnica, Jawor). Badania te pokazały, że gliny śląskie składają się głównie z materiałów ilastych, należących do krzemianów i glikokrzemianów warstwowych. Najczęściej identyfikowano minerały typu montmorillonitu (12 prób), które wchodzą w skład tzw. bentonitów, czyli skał ilastych uważanych za produkty wietrzenia szkliwa i tufów wulkanicznych. Obok montmorillonitów w bentonitach mogą występować domieszki innych minerałów - głównie kaolinitu i illitu (7 prób). Analizy te wykazały, że w glinie strzegomskiej głównym składnikiem ilastym jest montmorillonit, śladowo występuje w niej także metahaloizyt, cyrkon, dwuwodny szczawian wapnia oraz gips $^{38}$. W składzie mineralnym glin z okolic Złotoryi oprócz montmorillonitu stwierdzono ślady szczawianu wapnia, gruboziarnistego kwarcu, uwodnionych tlenków żelaza i serpentynu ${ }^{39}$. W składzie glin leczniczych z Legnicy poza illitem i kaolinitem występują też minerały mieszano-pakietowe, uwodnione tlenki żelaza i kwarc ${ }^{40}$. W charakterystyce opisywanych ziem wyodrębniono obecność następujących pierwiastków: żelazo, wapń, magnez, sód, tytan, bar, stront, nikiel, kobalt, miedź, mangan, molibden $^{41}$. Podobny skład chemiczny i mineralny wykazują także inne ziemie lecznicze, np. glina lecznicza z Gruzji, która również zaliczana jest do bentonitów z domieszką kaolinitu i kwarcu ${ }^{42}$. Dla porównania na budowę gliny z Lemnos składają się minerały ilaste, kaolinit, kwarc, drobny illit i śladowe ilości skalenia, plagioklazu i anatazu ${ }^{43}$. Interesujące z punktu widzenia medycznego wydają się właściwości fizyczne montmorillonitu. Wykazuje on przede wszystkim właściwości sorpcyjne, chłonie gwałtownie nie tylko wodę, ale także związki organiczne i roztwory soli mineralnych. Poza glinami o składzie montmorillonitowym

${ }^{37}$ W. Kowalski, A. Wiewióra, Terra Sigillata, „Prace Muzeum Ziemi”, 1974, nr 21, cz. 2, s. 3-57.

${ }^{38}$ Ibidem, s. 15.

${ }^{39}$ Ibidem.

${ }^{40}$ Ibidem, s. 16.

${ }^{41}$ Ibidem, s. 26.

${ }^{42}$ Ibidem, s. 28.

${ }^{43}$ D. Venieri, I. Gounaki, GE. Christidis, CW. Knapp, P. Bouras-Vallianatos, E. Photos-Jones, Bridging the gaps: bole and Terra Sigillata as artefacts, as simples and as antibacterial clays, „Minerals” 2020, t. 10, nr 4, s. 348. 
gliny śląskie wykazywały skład illitowy, kaolitowy, serpentynitowy i talkowy. Kaolin jest substancją pochodzenia mineralnego, zawierającą przede wszystkim kaolinit. Znane są złoża kaolinu, które zawierają do $99 \%$ czystego kaolinitu, a tylko $1 \%$ innych domieszek, które oddziela się przez szlamowanie. Kaolinit jest składnikiem większości glin pochodzenia zwietrzelinowego ${ }^{44}$. Spotykane obecnie w lecznictwie poszczególne gatunki kaolinu różnią się wielkością cząstek. Kaolin ma postać delikatnych, białych, miękkich w dotyku płatków w układzie heksagonalnym. W wodzie bardzo łatwo ulega dyspersji. Jest odporny na działanie kwasów i zasad, zmiana jego właściwości może nastąpić dopiero w dużych stężeniach, po dłuższym czasie działania w wysokiej temperaturze. Kaolin jest stosowany jako adsorbent w produkcji granulatów i tabletek. Wiele sproszkowanych ciał nierozpuszczalnych w wodzie, obojętnych pod względem chemicznym i nieulegających strawieniu $\mathrm{w}$ przewodzie pokarmowym, działa przeciwzapalnie na śluzówkę przewodu pokarmowego. Pokrywają one powierzchnię błony śluzowej warstwą izolującą ją od drażniącego wpływu treści pokarmowej, poza tym adsorbują wydzielinę zapalną powstałą na skutek działania bakterii i ich toksyny. Działają one przeciwzapalnie i hamują ruchy robaczkowe. Współcześnie kaolinit często jest składnikiem masy tabletkowej. Otrzymane tabletki są jednak twarde i mają przedłużony czas rozpadu. Spełnia także funkcję środka poślizgowego, zwłaszcza w przypadku tabletek, które zawierają wodę krystaliczną, ma bowiem zdolność jej wiązania. Środek ten jest często stosowany (łącznie z bentonitem i talkiem) do produkcji pudrów, stabilizowania zawiesin i past ${ }^{45}$. Talk to sproszkowany i oczyszczony, naturalny krzemian magnezu. Czysty talk może zawierać zmienne ilości towarzyszących minerałów, np.: magnezyt, kalcyt, dolomit. Substancja ta jest składnikiem wielu proszków, pudrów i zawiesin do stosowania zewnętrznego, np. znajduje zastosowanie w formie zasypki przy leczeniu zmian skórnych ${ }^{46}$.

\section{Podsumowanie}

Gliny w medycynie zaliczane są do peloidów (gr. pelos - błoto). Choć używane były do celów leczniczych przez tysiąclecia, pozostały $\mathrm{w}$ dużej mierze niezbadane $\mathrm{w}$ kwestii mechanizmu działania i poten-

${ }^{44}$ E. Sagan, M. Pakiet, op. cit., s. 11.

${ }^{45}$ S. Janicki, A. Fiebig, M. Szniatowska (red.), Farmacja Stosowana. Podręcznik dla studentów, Warszawa 2008, s. 672.

${ }^{46}$ A. Danysz, Farmakologia i Receptura, Warszawa 1971, s. 207-208. 
Terra sigillata Silesiaca - historyczne pokłady śląskiej gliny leczniczej...

cjalnych korzyści w medycynie. $\mathrm{W}$ ostatnim czasie można jednak zauważyć zwiększone zainteresowanie właściwościami geochemicznymi tych minerałów w kontekście bakteriobójczym i przeciwzapalnym ${ }^{47}$. Pojawienie się odpornych na antybiotyki patogenów przyspieszyło poszukiwania nowych źródeł związków przeciwbakteryjnych. Bakterie szybko uzyskują oporność na antybiotyki, które celują w specyficzne mechanizmy komórkowe, replikacje DNA, syntezę białek i ścian komórkowych. W efekcie tego znane od tysiącleci tradycyjne terapie, oparte na minerałach, zyskały uwagę naukowców. Zawiesina glinki Kisameet, używana od stuleci przez szczep Indian Heiltsuk, okazała się skuteczna przeciwko 16 szczepom opornych na wiele leków bakterii, powodujących większość infekcji wewnątrzszpitalnych, np. Enterococcus faecium, Staphylococcus aureus, Klebsiella pneumoniae, Acinetobacter baumannii, Pseudomonas aeruginosa i Enterobacter $s p{ }^{48}$ Wyniki badań sugerują, że glinka może zostać użyta jako opcja terapeutyczna do leczenia poważnych zakażeń spowodowanych przez te patogeny. Badania Williams i Heydel wskazują, że minerały ilaste stosowane przez Afroamerykanów do leczenia owrzodzenia Buruli, znanego jako flesh eating bacteria, przyspieszają gojenie się ran u osób zakażonych prątkami Mycobacterium ulcerans ${ }^{49}$. W innych badaniach Morrison i współautorzy wykazali, że niebieska glinka z Oregonu (Oregon Blue Clay) ma silne działanie bakteriobójcze zabija np. oporne na metycylinę gronkowce Staphylococcus aureus $(\mathrm{MRSA})^{50}$. Niebieskie glinki z Oregonu zawierają zredukowane metale i minerały ilaste, które pochłaniają kationy, zapewniając zdolność do przedłużonego uwalniania metalu i produkcji toksycznych rodników hydroksylowych. Efimenko i in. opisali z kolei działanie przeciwzapalne glinki z jeziora Tambukan w Rosji ${ }^{51}$. Lecznicza glina to nagroma-

${ }^{47}$ Por. K.D. Morrison, R. Misra, L.B. Williams, Unearthing the Antibacterial Mechanism of Medicinal Clay: A Geochemical Approach to Combating Antibiotic Resistan$c e$, ,Scientific Reports” 2016, nr 6, art. 19043, https://doi.org/10.1038/srep19043.

${ }^{48}$ S. Behroozian, S.L. Svensson, J. Davies, Kisameet Clay Exhibits Potent Antibacterial Activity against the ESKAPE Pathogens, „MBio.” 2016 , 7, 1; I. Spielvogel i in., op. cit., https://doi.org/10.1186/s13002-021-00437-0.

${ }_{49}$ Por. S. Adusumilli, S.E. Haydel, In vitro antibacterial activity and in vivo efficacy of hydrated clays on Mycobacterium ulcerans growth, „Complementary and Alternative Medicine" 2016, vol. 16, nr art. 40, s. 2-8; L.B. Williams, S.E. Haydel, op. cit., s. $745-770$.

${ }^{50}$ K.D. Morrison, R. Misra, L.B. Williams, op. cit.

51 N.V. Efimenko, A.V. Abramtsova, A.S. Kaysinova, The investigation of immunological effects of the new balneotherapeutic preparation glinofir used for the treatment of adjuvant arthritis, „Voprosy Kurortologii, Fizioterapii, i Lechebnoi Fizichesko i Kultury" 2016, 93, 4, s. 56-59. 


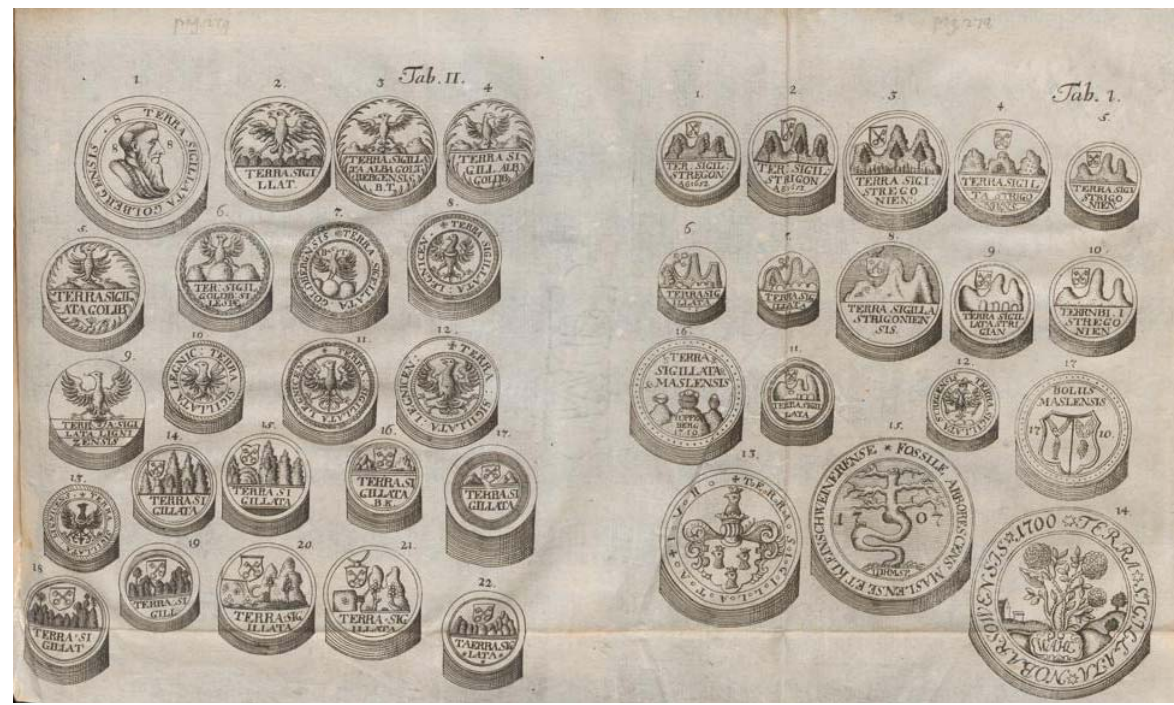

Rycina 1. Wzory pieczęci stosowanych do oznakowania pastylek ze śląskiej gliny lecznicze.

Źródło: Volkmann G.A., Silesia subterranea, oder Schiesien, mit seinen Unterirdischen Schatzen, Seltsamheiten, Leipzig 1720.

dzenia mieszaniny minerałów ilastych (m.in. smektytów, bentonitów, montmorillonitu, kaolinitu, illitu, metahaloizytu) z domieszkami innych minerałów i frakcji, utworzone bardzo często wskutek chemicznego wietrzenia skał i sedymentacji zwietrzelin. Stosunki ilościowe poszczególnych minerałów są bardzo zróżnicowane, podobnie jak zróżnicowany jest skład chemiczny. Kluczowe znaczenie dla zróżnicowania glin leczniczych ma rodzaj skał, z których wietrzenia pochodzą, warunki sedymentacji i procesy zachodzące po sedymentacji. Gliny lecznicze pochodzące $\mathrm{z}$ wietrzenia bazaltów mają inne właściwości niż np. z wietrzenia granitów, amfibolitów, gnejsów lub wapieni. $\mathrm{Z}$ opracowań tych wynika, że kluczowe działanie antybiotyczne glin leczniczych opiera się m.in. na mechanizmie zmiany $\mathrm{pH}$ środowiska, uniemożliwiając $\mathrm{w}$ ten sposób rozwój określonej grupy patogenów ${ }^{52}$. Analiza dostępnych materiałów na temat śląskiej gliny leczniczej daje nie tylko unikalny wgląd w medycynę dawną i sposoby leczenia, za-

${ }^{52}$ K.D. Morrison, J.C. Underwood, D.W. Metge, D.D. Eberl, L.B. Williams, Mineralogical variables that control the antibacterial effectiveness of a natural clay deposit, „Environmental Geochemistry and Health” 2014, vol. 36, nr 4, s. 613-631. 
nim rozwinął się przemysł farmaceutyczny. Studia nad wskazaniami i przeciwwskazaniami do stosowania terra sigillata Silesisca skłaniają bowiem do wysnucia wniosku, że ten środek terapeutyczny, którego stosowania zaprzestano, może stanowić interesujący punkt wyjścia do odkrywania nowych substancji leczniczych. Wiele współczesnych peloidów ma naukowo udowodnione właściwości lecznicze. Nieunikniona ewolucja oporności patogenów jest problemem globalnym, wymagającym nowatorskich/alternatywnych sposobów poszukiwania środków do ich zwalczania. W ostatnim czasie zauważa się zwiększone zainteresowanie źródłami historycznymi w procesie pozyskiwania nowych leków. Obecnie wydaje się interesujące, aby w oparciu o dostępne wiadomości spróbować odszukać materiał geologiczny glin leczniczych w celu pobrania próbek do badań laboratoryjnych w kierunku aktywności biologicznej (aktywność przeciwbakteryjna, aktywność dehydrogenaz, cytotoksyczność, proliferacja).

\section{Bibliografia}

\section{Źródła}

Berthold A., Terrae sigillatae nuper in Germania repertae, Frankfurt am Main 1583.

Brunner K., Schlesische terra sigilata, [w:] Weinhold K., Bolte J., Michel H. (red.), „Zeitschrift des Vereins für Volkskunde“, Jhg 21, H. 4, 1911.

Hermann L.D., Maslographia oder des schlesischen Massel im OelssBernstäditischen Fürstenthum mit seinen Schauwürdigkeiten, Breslau 1711.

Jaekel F.W., Über die Bazalte Niederschlesiens, „Jahres-Beticht der Schlesischen Gesellschaft für vaterländische Kultur” 1857, r. 35.

Kundmann J.Ch., Rariora naturae \& artis, item in re medica; oder, Seltenheiten der Natur und Kunst des kundmannischen Naturalien-Cabinets, wie auch in der Artzeney-Wissenschafft, Breslau 1737.

Marperger P.J., Schlesischer Kauffmann, Breslau-Leipzig 1714.

Poschadovsky-Wehner A., Geschichte des schlesischen uradligen Geschlechtes der Grafen Posadowsky-Wehner Freiherrn von Postelwitz: nebst einem Anhang enthaltend Nachrichten über das Breslauer Patrizier-Geschlecht von Wehner, Breslau 1891.

Schimmelpfennig A., Kundmann, Johann Christian, [w:] Allgemeine Deutsche Biographie, t. 17, Leipzig 1883. 
Schwenckfeld C., Stirpium \& Fossilium Silesiae Catalogus, Görlitz 1600.

Steinbeck A., Ueber die Siegelerde von Striegau, ,Jahres-Beticht der Schlesischen Gesellschaft für vaterländische Kultur” 1856, r. 34.

Volkmann G.A., Silesia subterranea, oder Schiesien, mit seinen Unterirdischen Schatzen, Seltsamheiten, Leipzig 1720.

Zedler J.H., Grosses vollständiges Universal Lexicon aller Wissenschaften und Künste, t. 42, Leipzig und Halle 1744.

\section{Opracowania}

Adusumilli S., Haydel S.E., In vitro antibacterial activity and in vivo efficacy of hydrated clays on Mycobacterium ulcerans growth, „Complementary and Alternative Medicine" 2016, vol. 16, nr art. 40.

Behroozian S., Svensson S.L., Davies J., Kisameet Clay Exhibits Potent Antibacterial Activity against the ESKAPE Pathogens, „MBio” 2016, 26, 7, 1: e01842-15.

Czubala D., O ludowym leczeniu glina w Polsce. Na podstawie badań przeprowadzonych w Polsce wśród garncarzy, „Lud” 1984, t. 68.

Dannenfeld K.H., The introduction of a new sixteen-century drug: terra Silesiaca, „Medical History” 1984, nr 28.

Don J., Żelaźniewicz A., The Sudetes-boundaries, subdivision and tectonic position, „Neues Jahrbuch für Geologie und Paläontologie” 1990, r. 179, nr 2/3.

Danysz A., Farmakologia i Receptura, Warszawa 1971.

Drygas A., Zarys dziejów farmacji z elementami zagadnień metodologicznych dla studentów farmacji, Gdańsk 1994.

Duffin C.J., "Fish", fossil and fake: medicinal unicorn horn, [w:] Duffin C.J., Gardner-Thorpe C., Moody R.T.J (red.), Geology and Medicine: Historical Connections, London 2017.

Efimenko N.V., Abramtsova A.V., Kaysinova A.S., The investigation of immunological effects of the new balneotherapeutic preparation glinofir used for the treatment of adjuvant arthritis, „Voprosy Kurortologii, Fizioterapii, i Lechebnoi Fizichesko i Kultury“ 2016, 93, 4 .

Gomes C.S., Healing and edible clays: a review of basic concepts, benefits and risks, „Environmental Geochemistry and Health” 2018, nr 40.

Gomes C.S., Naturotherapies Based on Minerals, „Geomaterials” 2013, v. 3, nr 1.

Harstick H.P., Der Kameralist Paul Jacob Marperger (1856-1730) über Armenwesen und Armenfürsorge, [w:] Becker U., Becker 
H.M., Kloosterman J. (red.), Kein Nachruf! Beiträge über und für Götz Langkau, Amsterdam 2003.

Janicki S., Fiebig A., Szniatowska M. (red.), Farmacja Stosowana. Podręcznik dla studentów, Warszawa 2008.

Kowalski W., Wiewióra A., Terra Sigillata, „Prace Muzeum Ziemi”, 1974, nr 21, cz. 2.

Macgregor A., Medicinal terra sigillata: a historical, geographical and typological review, [w:] Duffin C.J., Moody R.T.J, Gardner-Thorpe C. (red.), A History of Geology and Medicine, London 2013.

Morrison K.D., Misra R., Williams L.B., Unearthing the Antibacterial Mechanism of Medicinal Clay: A Geochemical Approach to Combating Antibiotic Resistance, „Scientific Reports” 2016, nr 6, nr art. 19043.

Morrison K.D., Underwood J.C., Metge D.W., Eberl D.D., Williams L.B, Mineralogical variables that control the antibacterial effectiveness of a natural clay deposit, „Environmental Geochemistry and Health" 2014, vol. 36, nr 4.

Pankiewicz H., Terra Sigillata, „Farmacja Polska” 1985, t. 41, nr 7.

Rankin A., On anecdote and antidotes: Poison trials in sixteenth-Century Europe, „Bulletin of the History of Medicine” 2017, v. 91, nr 2.

Roeske W., Terra Sigillata Liegnicensis „Biuletyn Informacji Polfa” 1967, nr 2.

Sagan E., Pakiet M., Terra Sigillata (katalog zbioru), Wałbrzych 1988.

Spałek K., Spielvogel I., The Use of Medicinal Clay from Silesia „Terra sigillata Silesiaca”, Central Europe - A New Chance for Natural Medicine?, „Biomedical Journal of Scientific \& Technical Research" 2019, t. 20, nr 3.

Spielvogel I., Spałek K., Badora K., Proćków J., Traditional knowledge and practice of the Triassic variegated clay from Silesia (Krasiejów), Poland, in human medicine, „Journal of Ethnobiology and Ethnomedicine” 2021, nr 17, nr art. 10, https://doi.org/10.1186/ s13002-021-00437-0.

Svensson S.L., Behroozian S., Xu W., Surette M.G., Li L., Davies J., Kisameet Glacial Clay: an Unexpected Source of Bacterial Diversity, „MBio” 2017, 8, 3, e00590-17.

Venieri D., Gounaki I., Christidis GE., Knapp CW., Bouras-Vallianatos P., Photos-Jones E., Bridging the gaps: bole and Terra Sigillata as artefacts, as simples and as antibacterial clays, „Minerals” 2020, t. $10, \mathrm{nr} 4$. 
Williams L.B., Haydel S.E., Evaluation of the medicinal use of clay minerals as antibacterial agents, „International Geology Review” 2010, 1, 52, 7/8.

Żelaźniewicz A., The Sudetes as a Paleozoic orogen in Central Europe, „Geological Magazine” 1997, nr 134. 